\title{
Rapid Sequestration and Degradation of Somatostatin Analogues by Isolated Brain Microvessels
}

\author{
William M. Pardridge, Jody Eisenberg, and Tadataka Yamada \\ Departments of Medicine, UCLA School of Medicine, Los Angeles, California, and University of Michigan School \\ of Medicine, Ann Arbor, Michigan, U.S.A.
}

\begin{abstract}
Somatostatin (SRIF) is a putative peptide neurotransmitter that may interact with brain capillaries following neurosecretion of the peptide. The present studies investigate the binding and metabolism of SRIF analogues in isolated bovine brain microvessels. ${ }^{125} \mathrm{I}$ [Tyr $\left.{ }^{\prime}\right]$ SRIF was rapidly degraded by capillary aminopeptidase with a half-time of approximately $3 \mathrm{~min}$ at $23^{\circ} \mathrm{C}$. The microvessel aminopeptidase had a low affinity and high capacity for the peptide, $K_{\mathrm{m}}=76 \mu M$ and $V_{\max }=$ $74 \mathrm{nmol} \mathrm{min}{ }^{-1} \mathrm{mg}_{\mathrm{n}}{ }^{-1} .{ }^{125}$ I-[Tyr ${ }^{11}$ ]SRIF was converted to free iodotyrosine at a much slower rate, presumably by a lower-activity endopeptidase. ${ }^{125} \mathrm{I}$-[Tyr ${ }^{11}$ ]SRIF was rapidly bound by microvessels, whereas another basic peptide, $\left[\mathrm{Tyr}^{8}\right]$ bradykinin, or an acidic peptide, CCK8, or a neutral peptide, leucine enkephalin, were bound to a considerably less extent. The binding of ${ }^{125}$ I-[Tyr $\left.{ }^{11}\right] S R I F$ to the capillaries was nonsaturable up to a concentration of $1 \mu \mathrm{g} / \mathrm{ml}$ of unlabeled peptide, and the binding reaction
\end{abstract}

was extremely rapid, reaching equilibrium within $5 \mathrm{~s}$ at either $0^{\circ} \mathrm{C}$ or $37^{\circ} \mathrm{C}$. Approximately $20 \%$ of the SRIF bound by the microvessels was resistant to acid wash and presumably represented internalized peptide. In addition, the ${ }^{125} \mathrm{I}$-[Tyr $\left.{ }^{11}\right]$ SRIF bound rapidly to the endothelial cytoskeleton remaining after a $1 \%$ Triton $\mathrm{X}-100$ extraction of the microvessels. The peptide-cytoskeletal binding reaction was nonsaturable up to $1 \mu \mathrm{g} / \mathrm{ml}$ of unlabeled $\left[\mathrm{Tyr}^{11}\right]$ SRIF, but it was inhibited by $0.5 \%$ polylysine or $0.8 \mathrm{M} \mathrm{KCl}$ and was stimulated by $1 \mathrm{~m} M$ dithiothreiotol. These studies suggest that brain microvessels rapidly sequester and degrade SRIF analogues and that this may represent one mechanism for rapid inactivation of the neuropeptides subsequent to neurosecretion. Key Words: Aminopeptidase-Cytoskeleton-Peptides. Pardridge W. M. et al. Rapid sequestration and degradation of somatostatin analogues by isolated brain microvessels. $J$. Neurochem. 44, 1178-1184 (1985).
Brain capillaries make up the blood-brain barrier (BBB) in vivo. Previous studies of peptide interactions with brain capillaries have focused on circulating peptides such as insulin, and receptors for insulin have been shown to exist on the luminal aspect of the brain capillary (Pardridge, 1983). In addition to circulating peptides, it is likely that brain capillaries interact with brain-derived peptides which may function as neurotransmitters (Krieger and Martin, 1981) or neuromodulators of cerebral blood flow (Lindvall and Owman, 1981; Hanko et al., 1982). For example, vasoactive intestinal peptide (VIP), neurotensin, substance $P$, and bombesin have all been localized in brain vessel walls (Uddman et al., 1981, 1983; Hanko et al., 1982). In the cat, VIP produces dilatation and somatostatin (SRIF) causes vasoconstriction of the pial artery
(Hanko et al., 1982). It is possible that neuropeptides such as VIP or SRIF regulate blood flow by interacting with arteriolar smooth muscle cells. In addition, neuropeptides may interact with capillary endothelial cells to modulate endothelial permeability to circulating water, nutrients, or plasma proteins in parallel to peptide alterations in cerebral blood flow (Heistad et al., 1981). Moreover, the site of neuropeptide enzymatic inactivation in brain remains unknown and may be localized in brain capillary endothelia. For example, previous studies have shown that a tyrosine-directed aminopeptidase (Pardridge and Mietus, 1981) and a dipeptidyl dipeptidase activity (Brecher et al., 1978) are present in brain capillaries. Therefore, the present studies were designed to assess brain capillary binding and metabolism of a model neuropeptide,
Received June 20, 1984; accepted October 2, 1984.

Address correspondence and reprint requests to William $M$. Pardridge, M.D., Department of Medicine, UCLA School of Medicine, Los Angeles, CA 90024 , U.S.A.

This work was presented in abstract form at the Society of Neuroscience meetings, Anaheim, California, October, 1984.
Abbreviations used: BBB, Blood-brain barrier; DMEM, Dulbecco's modified Eagle's medium; DMSO, Dimethyl sulfoxide; HEPES, $N$-2-Hydroxyethylpiperazine- $N^{\prime}$-2-ethanesulfonic acid; RHB, Ringer-HEPES buffer; SRIF, Somatostatin; TFA, Trifluoroacetic acid; VIP, Vasoactive intestinal peptide. 
SRIF, using two different analogues, [Tyr $\left.{ }^{1}\right]$ SRIF and $\left[\right.$ Tyr $\left.^{11}\right]$ SRIF.

\section{MATERIALS AND METHODS}

\section{Isolation of brain microvessels}

Microvessels were isolated from the brains of mature steers using modifications of the mechanical homogenization technique of Goldstein et al. (1975). This preparation consists primarily of capillaries, but also contains minor amounts of small arterioles as well as erythrocytes trapped in the microvessel lumen. Steer brains were obtained on the morning of isolation from a local slaughterhouse and transported to the lab in ice-cold buffer $\mathrm{B}(103$ $\mathrm{m} M \mathrm{NaCl}, 4.7 \mathrm{~m} M \mathrm{KCl}, 2.5 \mathrm{~m} M \mathrm{CaCl}_{2}, 1.2 \mathrm{~m} M \mathrm{KH}_{2} \mathrm{PO}_{4}$, $1.2 \mathrm{~m} M \mathrm{MgSO}_{4}, 15 \mathrm{~m} M N$-2-hydroxyethylpiperazine- $N^{\prime}$ 2-ethanesulfonic acid (HEPES), pH 7.4). Approximately $80 \mathrm{~g}$ of cortex was scraped off two brains after the removal of the pial membrane. Brain tissue was homogenized in a fivefold volume excess of buffer $A$ with a handheld Teflon homogenizer with a $0.25-\mathrm{mm}$ clearance using 13 up-and-down strokes. Buffer A consisted of buffer B plus $25 \mathrm{~m} M \mathrm{NaHCO}_{3}, 10 \mathrm{~m} M$ glucose, $1 \mathrm{~m} M$ sodium pyruvate, and $1 \mathrm{~g} / 100 \mathrm{ml}$ bovine albumin. The homogenate was suspended in an equal volume of $26 \%$ dextran $(\mathrm{MW}=79,500)$ to yield a final $13 \%$ dextran, and was centrifuged for $10 \mathrm{~min}$ at $5,800 \mathrm{~g}$ at $4^{\circ} \mathrm{C}$. The pellet was pooled in $20 \mathrm{ml}$ of buffer $\mathrm{A}$ and passed over a $210 \mu \mathrm{m}$ nylon mesh (Tetko, Elmsford, NY). The arterioles were left on top of the mesh and the capillaries, red cells, and nuclei were collected as the filtrate through the mesh. This mixture was passed over a $3 \times 4-\mathrm{cm}$ glass bead column $(0.45-\mathrm{mm}$ glass beads) and the column was washed with $400 \mathrm{ml}$ of buffer $A$. The glass beads with the adherent microvessels were transferred to a beaker and swirled, and the beads were allowed to settle. The supernatant containing the microvessels was decanted and spun at $500 \mathrm{~g}$ for $5 \mathrm{~min}$ at $4^{\circ} \mathrm{C}$ and resuspended in buffer A minus $\mathrm{CaCl}_{2}$ for cryopreservation at $-70^{\circ} \mathrm{C}$ in $10 \%$ dimethyl sulfoxide (DMSO) and $0.5 \mathrm{~g} / 100 \mathrm{ml}$ bovine albumin. The capillaries were recovered from the cryopreservation with a $50 \%$ yield. No changes in SRIF sequestration by microvessels were observed in the cryopreserved capillaries as compared with the freshly isolated capillaries.

Bovine brain capillary endothelial cells were also prepared by the method of Bowman et al. (1983). Cortex was obtained from two bovine brains and placed in approximately $250 \mathrm{ml}$ of Dulbecco's modified Eagle medium (DMEM); then the tissue was minced with a razor blade on a petri dish. This solution was brought to $500 \mathrm{ml}$ with DMEM and dispase was added to a final concentration of $0.5 \%$. The solution was then placed at $37^{\circ} \mathrm{C}$ and was stirred for approximately $2 \mathrm{~h}$. The homogenate was centrifuged at $1,000 \mathrm{~g}$ at $4^{\circ} \mathrm{C}$ for $10 \mathrm{~min}$ and the pellet was resuspended in $250 \mathrm{ml}$ of DMEM containing $13 \%$ dextran. This suspension was then centrifuged at $5,800 \mathrm{~g}$ for 10 min at $4^{\circ} \mathrm{C}$. The pellets were pooled in $20 \mathrm{ml}$ of DMEM and passed over a $210 \mu \mathrm{m}$ nylon mesh as described above. At this stage, more than $95 \%$ of the microvessels obtained with the enzymatic homogenization technique excluded trypan blue. We found that passage of these microvessels over a glass bead column substantially increased the fraction of trypan blue-positive microvessels.
Consequently, the glass bead column step was omitted and the microvessels were separated from the red blood cells with two sequential Percoll density gradient centrifugations. The microvessels and red cells that passed through the $210 \mu \mathrm{m}$ nylon mesh were concentrated by centrifugation at $1,000 \mathrm{~g}$ for $5 \mathrm{~min}$ at $4^{\circ} \mathrm{C}$. The pellet was resuspended in a small volume of DMEM and was layered on top of a pre-established 50\% Percoll gradient in medium 199 and $30 \mathrm{mM}$ Na HEPES (pH 7.4) and centrifuged at $1,000 \mathrm{~g}$ at $4^{\circ} \mathrm{C}$ for $10 \mathrm{~min}$. The Percoll gradient resulted in the formation of three layers: a top layer of cellular debris, a middle layer of microvessels, and a bottom layer of red cells. The middle microvessel layer was collected and washed free of Percoll with DMEM. Since this layer was still contaminated with red cells after or e Percoll gradient, the microvessel layer was applied to a second pre-established 50\% Percoll gradient and centrifuged as described above. Complete elimination of the red cells from the microvessel preparation was not possible since the microvessels isolated with an enzymatic homogenization technique contained numerous red cells within the lumen of the capillary. The Percoll gradient was pre-established by centrifugation of the Percoll-medium 199 mixture in a fixed-angle rotor at 27,000 $\mathrm{g}$ for 50 $\min$ at $4^{\circ} \mathrm{C}$. The final microvessels prepared with the enzymatic homogenization technique were more than $90 \%$ trypan blue negative. Conversely, the capillaries obtained with the mechanical homogenization were approximately 90\% trypan blue positive.

\section{Incubation conditions}

Approximately $150 \mu \mathrm{g}$ of protein from microvessels was mixed with various concentrations of ${ }^{125} \mathrm{I}-\left[\mathrm{THy}^{1}\right] \mathrm{SRIF}$ or ${ }^{125} \mathrm{I}$-[Tyr $\left.{ }^{11}\right]$ SRIF and $\left[{ }^{3} \mathrm{H}\right.$ ]inulin (used as an extravascular space marker) in $450 \mu \mathrm{l}$ of Ringer-HEPES buffer (RHB: $141 \mathrm{~m} M \mathrm{NaCl}, 4 \mathrm{~m} M \mathrm{KCl}, 2.8 \mathrm{~m} M \mathrm{CaCl}_{2}, 10 \mathrm{~m} M$ HEPES, $\mathrm{pH} 7.4$ ) containing $0.1 \mathrm{~g} / 100 \mathrm{ml}$ bovine albumin. The ratio of ${ }^{125} \mathrm{I} /{ }^{3} \mathrm{H}$ was maintained at 0.1 . The microvessels and isotopes were incubated at either $4^{\circ} \mathrm{C}, 23^{\circ} \mathrm{C}$, or $37^{\circ} \mathrm{C}$ for various times. At the end of the incubation, 400 $\mu \mathrm{l}$ of this mixture was rapidly centrifuged at $10,000 \mathrm{~g}$ in a microfuge for $45 \mathrm{~s}$; the supernatant was aspirated and the tip of the tube was cut with a razor blade into $0.5 \mathrm{ml}$ $1 M \mathrm{NaOH}$ and counted for ${ }^{125} \mathrm{I}$. This mixture was then heated at $60^{\circ} \mathrm{C}$ for $30 \mathrm{~min}$ to solubilize the protein, and microvessel protein was measured with the method of Lowry et al. (1951). Another aliquot of the $\mathrm{NaOH}$ extract was removed for liquid scintillation counting of the ${ }^{3} \mathrm{H}$ radioactivity in the presence of ${ }^{125} I$ as described previously (Pardridge, 1979). The percent bound ${ }^{125} \mathrm{I}$ and ${ }^{3} \mathrm{H}$ radioactivity per milligram of microvessel protein was computed. The $\left[{ }^{3} \mathrm{H}\right]$ inulin uptake, which ranged from $1-$ $3 \% \mathrm{mg}$ protein, was subtracted from each ${ }^{125} \mathrm{I}$-SRIF uptake per milligram of protein to account for isotope trapped in the extracellular space of the microvessel pellet.

The internalization of ${ }^{125}$ I-SRIF was assessed with an acid-wash technique which has been used successfully to measure the internalization of ${ }^{125}$ I-insulin by fat cells (Olefsky and Kao, 1982) and by brain microvessels (Pardridge et al., 1985). After incubating the capillaries at various times with ${ }^{125}{ }^{2}$-[Tyr $\left.{ }^{11}\right]$ SRIF, $400 \mu$ l of the microvessel solution was transferred to $1.5-\mathrm{ml}$ Beckman microfuge tubes and centrifuged at $10,000 \mathrm{~g}$ for $45 \mathrm{~s}$. The supernatant was aspirated and the microvessel pellet was 
resuspended in $450 \mu$ l of cold acid wash buffer $(0.028 \mathrm{M}$ sodium acetate, $0.12 \mathrm{M} \mathrm{NaCl}, 0.02 M$ sodium barbital, $\mathrm{pH} 3.0$ ) and was placed on ice for $6 \mathrm{~min}$. Then $400 \mu \mathrm{l}$ of the mixture was transferred to small Beckman microfuge tubes and was centrifuged at $10,000 \mathrm{~g}$ for $45 \mathrm{~s}$. The supernatant was aspirated, the tubes were drained, and the pellets were cut into $0.5 \mathrm{ml} 1 \mathrm{MNaOH}$ and were analyzed as described above. Data are presented as means of duplicates or triplicates that varied less than $20 \%$ from the mean.

Microvessel cytoskeletons were prepared by suspending microvessel pellets in Triton extraction buffer (0.05 $M$ HEPES, 0.15 $M \mathrm{NaCl}, 1 \mathrm{~m} M$ EGTA, $1 \%$ Triton $\mathrm{X}-100, \mathrm{pH} 7.4)$ at $23^{\circ} \mathrm{C}$ for $10 \mathrm{~min}$. The solution was then centrifuged at $10,000 \mathrm{~g}$ for $10 \mathrm{~min}$ at $23^{\circ} \mathrm{C}$. The supernatant was aspirated and the microvessel cytoskeletal pellet was suspended in $4 \mathrm{ml}$ of wash buffer $(0.05$ HEPES, 0.15 $M \mathrm{NaCl}, 1 \mathrm{~m} M$ EGTA, $\mathrm{pH} 7.4)$ and centrifuged at 10,000 $g$ for $5 \mathrm{~min}$ at $23^{\circ} \mathrm{C}$. The supernatant was discarded and the microvessel cytoskeleton was washed one more time with wash buffer followed by centrifugation. The final cytoskeletal pellet was resuspended in $1.5 \mathrm{ml}$ of wash buffer and was added to individual tubes containing wash buffer, ${ }^{125} \mathrm{I}-\left[\mathrm{Tyr}^{11}\right] \mathrm{SRIF},\left[{ }^{3} \mathrm{H}\right]$ inulin, and various concentrations of additives (see Results) in a final volume of $450 \mu \mathrm{l}$.

\section{High-performance liquid chromatography}

Degradation studies were performed the day of the capillary isolation. Approximately $10 \mathrm{mg} /$ protein of microvessels were suspended in RHB containing $0.3 \mu \mathrm{Ci} / \mathrm{ml}$ ${ }^{125} \mathrm{I}-\left[\mathrm{Tyr}^{11}\right] \mathrm{SRIF}$ or ${ }^{125} \mathrm{I}-\left[\mathrm{Tyr}^{1}\right] \mathrm{SRIF}$ at $23^{\circ} \mathrm{C}$ for up to 20 min of incubation. At various times of incubation, $0.4 \mathrm{ml}$ of microvessels were removed from the incubation and rapidly centrifuged at $10,000 \mathrm{~g}$ for $30 \mathrm{~s}$ at $4^{\circ} \mathrm{C}$. The medium was aspirated and $0.2 \mathrm{ml}$ of the medium was mixed with equal volumes of $2 \mathrm{M}$ acetic acid and stored at $4^{\circ} \mathrm{C}$. The microfuge tip containing the microvessel pellet was cut from the tube and placed in $1 \mathrm{ml}$ of acid ethanol $(75 \%$ ethanol; $15 \% 1 \mathrm{M} \mathrm{HCl}$ ) and was placed at $4^{\circ} \mathrm{C}$ overnight. The following day, the cell extract was vortexed and then centrifuged at $1,000 \mathrm{~g}$ at $4^{\circ} \mathrm{C}$ for $15 \mathrm{~min}$. A $0.7-\mathrm{ml}$ aliquot was removed for HPLC analysis of the acid extract. Recovery of SRIF standards from the acid ethanol extraction was $72 \pm 6 \%$ (mean $\pm \mathrm{SE}$ ).

HPLC runs were performed on a $\mu$ Bondapak $C_{18}$ column $(0.39 \times 30 \mathrm{~cm}$, Waters Assoc., Milford, MA) using an Altex Scientific model 312 MP chromatography system. The buffers used for elution were $2 \%$ trifluoroacetic acid (TFA) (buffer $A$ ) and $50 \%$ acetonitrile in $2 \%$ TFA (buffer B). The column was eluted at a flow rate of $1 \mathrm{ml} / \mathrm{min}$ at room temperature using the following protocol: $5 \mathrm{~min}$ at $0 \% \mathrm{~B}, 17.5 \mathrm{~min}$ gradient of $0-70 \% \mathrm{~B}, 10$ min at $70 \% \mathrm{~B}$, and 5 min gradient at $70-0 \% \mathrm{~B}$. Eluted fractions were collected and counted for ${ }^{125} I$.

\section{Miscellaneous methods}

$\left[\mathrm{Tyr}^{1}\right]$ SRIF, [Tyr $\left.{ }^{11}\right]$ SRIF, CCK8, and $\left[\mathrm{Tyr}^{8}\right]$ bradykinin were iodinated with chloramine $\mathrm{T}$ and $\left[{ }^{125} \mathrm{I}\right]$ iodine as described previously (Yamada et al., 1980). Proteins were determined with the method of Lowry et al. (1951).

\section{Materials}

$\left[{ }^{125}\right.$ I]Iodine was obtained from New England Nuclear Corp. (Boston, MA). [Tyr $\left.{ }^{1}\right]$ SRIF, $\left[\right.$ Tyr $\left.^{8}\right]$ bradykinin, and

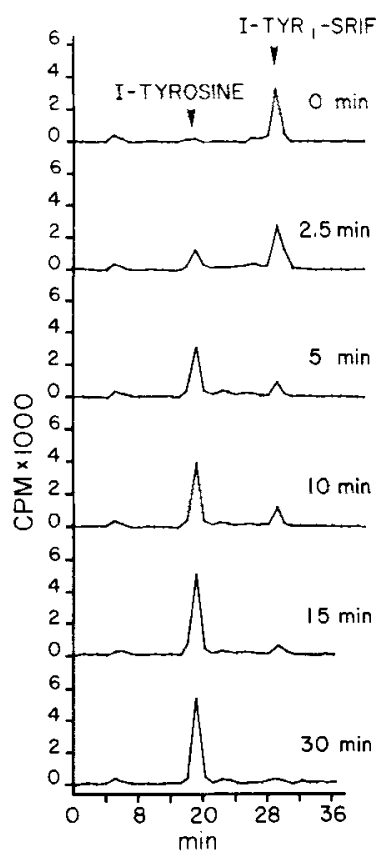

FIG. 1. HPLC profile of medium at various times of incubation of the bovine brain microvessels with 125 . $\left[\right.$ Tyr $\left.^{1}\right]$ SRIF at $23^{\circ} \mathrm{C}$. The migration of iodotyrosine (1-tyrosine) and iodo-[Tyr $\left.{ }^{1}\right]$ SRIF internal standards is denoted by the arrows. The ${ }^{125} \mid-$ [Tyr ${ }^{1}$ ]SRIF was rapidly converted to free ${ }^{125}$-tyrosine with a half-time of approximately $3 \mathrm{~min}$ at $23^{\circ} \mathrm{C}$. The amount of microvessels in each incubation was approximately $0.8 \mathrm{mg}$ microvessel protein per $0.5 \mathrm{ml}$ of incubation medium.

CCK8 were obtained from Peninsula Labs (Belmont, CA). [Tyr $\left.{ }^{11}\right]$ SRIF was obtained from Bachem Labs (Torrance, CA). lodotyrosine, polylysine-4000, and dextran $(\mathrm{MW}=79,500)$ were obtained from Sigma Chemical Co. (St. Louis, MO). Dispase (neutral protease) was purchased from Boehringer-Mannheim (Indianapolis, IN). Bovine albumin (pentex fraction $V$ ) was purchased from Miles Labs (Elkhart, IN).

\section{RESULTS}

\section{Capillary degradation of [ Tyr $\left.^{1}\right]$ SRIF}

Initial studies were performed with [Tyr ${ }^{1}$ ]SRIF. Prior to binding studies with this analogue, degradation studies were carried out. Aminopeptidase degradation of the peptide could result in the formation of free iodotyrosine and artifactual labeling of the microvessels as described previously with leucine enkephalin labeled at the N-terminal tyrosine (Pardridge and Mietus, 1981). As shown in Fig. 1 , the incubation analyzed by HPLC showed a progressive increase in medium radioactivity comigrating with an iodotyrosine internal standard. The $t_{1 / 2}$ of [Tyr ${ }^{1}$ ]SRIF degradation by the microvessels was approximately $3 \mathrm{~min}$ at room temperature. The saturability of $\left[\mathrm{Tyr}^{1}\right]$ SRIF by capillary aminopeptidase is shown in Fig. 2. In these studies, approximately $5 \mathrm{mg}$ protein of brain microvessels were incubated in $5 \mathrm{ml}$ of $\mathrm{RHB}$ at $23^{\circ} \mathrm{C}$ for $2 \mathrm{~min}$ in the presence of $0.01-100 \mu M$ [Tyr $^{1}$ ]SRIF. At the end of the incubation, the microvessels were rapidly centrifuged in a microfuge for $60 \mathrm{~s}$, and acetic acid was added to the supernatant to achieve a concentration of $0.5 \mathrm{M}$. The acid medium extract was placed overnight at $4^{\circ} \mathrm{C}$ and the percent free iodotyrosine in the incubation mixture was assessed by HPLC using 

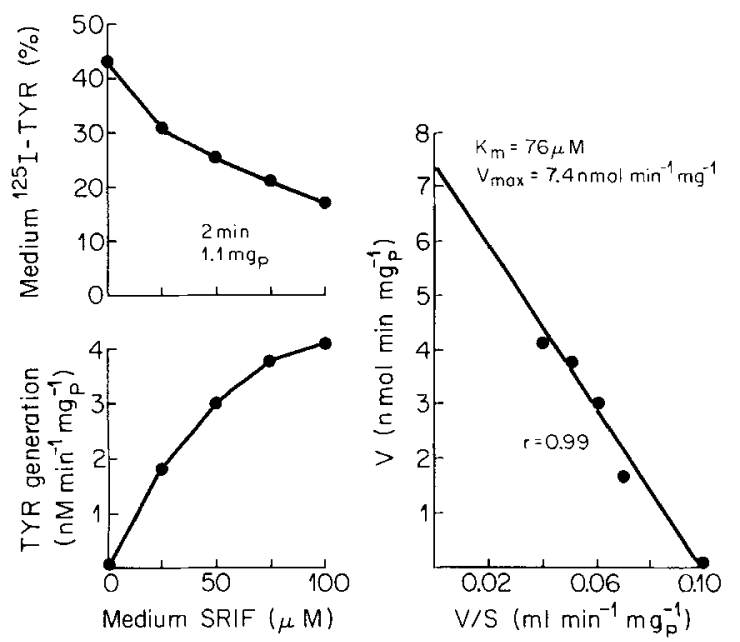

FIG. 2. The incubation shown in Fig. 1 was repeated at $2 \mathrm{~min}$ at $23^{\circ} \mathrm{C}$ with various concentrations $(0.01-100 \mu \mathrm{M})$ of unlabeled Tyr-1-SRIF and $0.5 \mu \mathrm{Ci} / \mathrm{ml}^{125}$-[Tyr ${ }^{1}$ ]SRIF. The medium was processed and analyzed by HPLC (Materials and Methods) and the percent of ${ }^{125}$-tyrosine in the medium was determined (upper left) and the rate of aminopeptidase activity was calculated (lower left). An Eadie-Hofstee plot (right) of the saturation data provides estimates of the aminopeptidase $K_{m}$ and $V_{\max }$ for [Tyr $\left.{ }^{1}\right] S R I F$.

the conditions shown in Fig. 1. The rate of microvessel aminopeptidase degradation of $\left[\mathrm{Tyr}^{1}\right] \mathrm{SRIF}$ was calculated from the medium percent iodotyrosine and the SRIF concentration. An Eadie-Hofstee plot shows that the capillary aminopeptidase degradation of [Tyr']SRIF is characterized by a relatively low affinity (high $K_{\mathrm{m}}$ ) and high capacity (high $V_{\max }$ ).

\section{Binding studies using ${ }^{125} \mathrm{I}-\left[\mathrm{Tyr}^{11}\right]$ SRIF}

Microvessels were incubated with ${ }^{125}\left[-\left[\mathrm{Tyr}^{11}\right]\right.$ SRIF for periods ranging from $5 \mathrm{~s}$ to $30 \mathrm{~min}$ at $23^{\circ} \mathrm{C}$. The uptake during this time period was constant (data not shown) and was proportional to the amount of microvessel protein (Table 1). HPLC analysis (not shown) of the medium extract at 30 min of incubation at $23^{\circ} \mathrm{C}$ showed that more than $75 \%$ of the medium radioactivity coeluted with a ${ }^{125}$ I-[Tyr $\left.{ }^{11}\right]$ SRIF standard. The uptake or binding of $\left[\right.$ Tyr $\left.^{11}\right]$ SRIF at any time up to $30 \mathrm{~min}$ of incubation

TABLE 1. Effect of microvessel concentration on binding of ${ }^{I 25} I-\left[T y r^{l 1}\right] S R I F$

\begin{tabular}{cc}
\hline$\mu \mathrm{g}_{\mathrm{p}}$ & Percent bound \\
\hline $56 \pm 13$ & $1.6 \pm 0.6$ \\
$158 \pm 7$ & $5.8 \pm 1.2$ \\
$402 \pm 3$ & $12.0 \pm 3.3$ \\
\hline
\end{tabular}

Data are mean $\pm \mathrm{SE}(\mathrm{n}=3)$. The uptake of $\left[{ }^{3} \mathrm{H}\right]$ inulin, an extracellular space marker, was measured simultaneously and was subtracted from the measured uptake of ${ }^{125} \mathrm{I}-\left[\mathrm{Ty} \mathrm{r}^{11}\right] \mathrm{SRIF}$. The microvessels were incubated with the isotopes at $23^{\circ} \mathrm{C}$ for $10 \mathrm{~min}$.

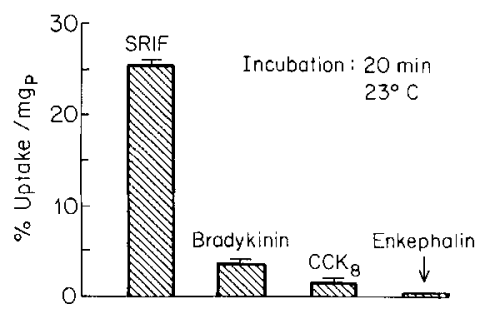

FIG. 3. The brain uptake of four different peptides by bovine brain capillaries during a $20-\mathrm{min}$ incubation at $23^{\circ} \mathrm{C}$ is shown for ${ }^{125}$ I-[Tyr $\left.{ }^{11}\right]$ SRIF, ${ }^{125} \mid-\left[\right.$ Tyr $\left.^{8}\right]$ bradykinin, ${ }^{125} \mid$-CCK8, and $\left[{ }^{3} \mathrm{H}\right]$ leucine enkephalin. [The $\left[{ }^{3} \mathrm{H}\right]$ leucine enkephalin is from Pardridge and Mietus (1981).] The uptake of $\left[{ }^{3} \mathrm{H}\right]$ inulin, an extracellular space marker, was measured simultaneously and was subtracted from the total uptake for each of the ${ }^{125}$. peptides.

at room temperature was not saturated by the addition of unlabeled [Tyr ${ }^{11}$ ]SRIF to the medium at concentrations as high as $1 \mu \mathrm{g} / \mathrm{ml}$ (data not shown). The high degree of nonspecific binding of $\left[\mathrm{Tyr}^{11}\right]$ SRIF was not seen with another basic peptide, such as $\left[\mathrm{Tyr}^{8}\right]$ bradykinin, with an acidic peptide, such as CCK8, or with a neutral peptide, such as leucine enkephalin (Fig. 3). In addition, the nonspecific binding of [Tyr $\left.{ }^{11}\right]$ SRIF to the microvessels was independent of incubation temperature (Fig. 4). About $15-20 \%$ of the [Tyr $\left.{ }^{11}\right]$ SRIF sequestered by the microvessels was resistant to a mild acid wash (Fig. 4) indicating the majority of the peptide was bound to the exterior cell surface. Also, the late addition of various dilutions of an antisera directed against $\left[\right.$ Tyr $\left.^{11}\right]$ SRIF to the incubation media resulted in a progressive decrease in the amount of peptide sequestered by the microvessel (Table 2).

The amount of $\left[\mathrm{Tyr}^{11}{ }^{1}\right] \mathrm{SRIF}$ bound to the microvessel was constant for up to $30 \mathrm{~min}$ at $4^{\circ} \mathrm{C}$ (Fig. 4)

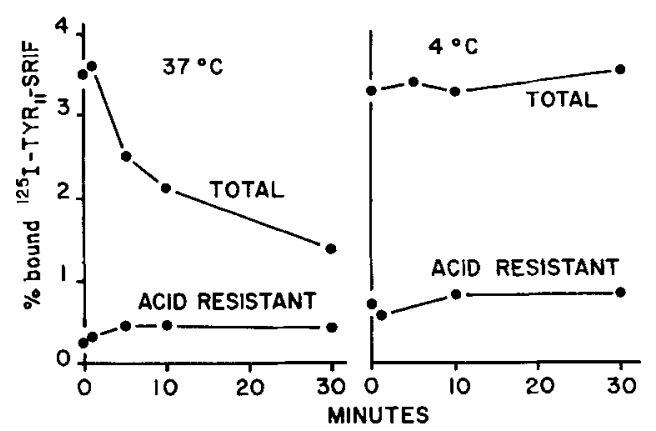

FIG. 4. The percent of ${ }^{125}{ }^{-[}$Tyr $\left.^{11}\right]$ SRIF bound to brain capillaries at $37^{\circ} \mathrm{C}$ or $4^{\circ} \mathrm{C}$ is shown versus incubation time. The earliest time point in all curves is $5 \mathrm{~s}$ of incubation. The acidresistant portion of the total binding was determined by a mild acid wash of the microvessels at $4^{\circ} \mathrm{C}$ subsequent to incubation (Materials and Methods). The decay in microvessel-bound SRIF at $37^{\circ} \mathrm{C}$ presumably represents endopeptidase degradation of the SRIF analogue (see Fig. 5) and release of the radiolabeled SRIF metabolite. The uptake of $\left[{ }^{3} \mathrm{H}\right]$ inulin, an extracellular space marker, was measured simultaneously and was subtracted from the total uptake for each of the ${ }^{125}$-peptides. 
FIG. 5. HPLC profile of acid ethanol extract of the microvessel pellet at various times of incubation at $23^{\circ} \mathrm{C}$ with 125 I[Tyr ${ }^{11}$ ] program is identical to that shown in Fig. 1 and described in Materials and Methods; the unmetabolized [Tyr ${ }^{11}$ ]SRIF eluted at approximately $28 \mathrm{~min}$ and the free iodotyrosine eluted at approximately $19 \mathrm{~min}$. The microvessel concentration in these incubations was $1 \mathrm{mg}_{\mathrm{p}} / \mathrm{ml}$.

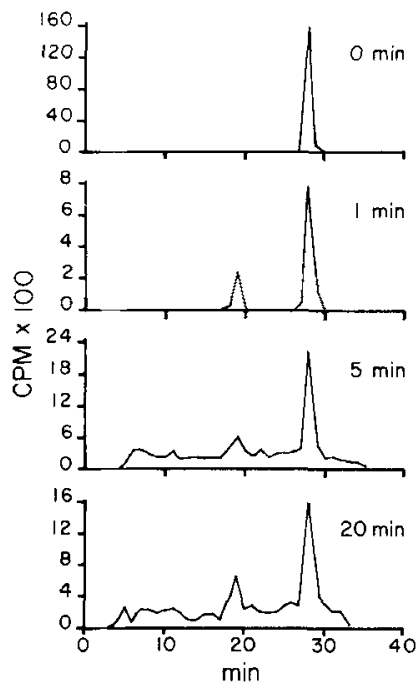

or at $23^{\circ} \mathrm{C}$ (data not shown). However, at $37^{\circ} \mathrm{C}$, the amount of ${ }^{125} \mathrm{I}$-[ $\mathrm{Tyr}^{11}$ ]SRIF associated with the microvessel decreased rapidly with incubation time. The release of the peptide from the microvessel at physiologic temperatures is likely due to endopeptidase degradation of the peptide by the microvessel. As shown in Fig. 5, HPLC analysis of the cell extract of the microvessel after $0-, 1-, 5-$, or $20-$ min incubations with ${ }^{125} \mathrm{I}-\left[\mathrm{Tyr}^{11}\right] \mathrm{SRIF}$ at $23^{\circ} \mathrm{C}$ resulted in the formation of multiple minor radioactive peaks with a prominent peak that comigrated with the iodotyrosine internal standard. HPLC profiles of the cell extract after incubation at $37^{\circ} \mathrm{C}$ were not performed.

\section{Binding of [Tyr $\left.{ }^{11}\right]$ SRIF to} microvessel cytoskeleton

To test whether the [Tyr $\left.{ }^{11}\right]$ SRIF sequestration to the microvessel involved binding of the peptide to the microvessel cytoskeleton, the studies shown in Fig. 6 were performed. Microvessels were incubated in buffer containing $1 \%$ Triton $\mathrm{X}-100$ at room temperature for $10 \mathrm{~min}$ and the microvessel pellet formed after centrifugation was used as the cytoskeleton (Materials and Methods). Binding of the

TABLE 2. Effects of anti-[Tyr"]SRIF sheep antiserum on the microvessel uptake of ${ }^{125} I-\left[T y r^{11}\right] S R I F$

\begin{tabular}{cc}
\hline Antisera dilution & Percent bound/mg \\
\hline control & $11.1 \pm 0.9$ \\
$1: 50,000$ & $10.9 \pm 1.4$ \\
$1: 10,000$ & $7.5 \pm 0.1$ \\
$1: 5,000$ & $5.7 \pm 0.2$ \\
$1: 1,000$ & $2.9 \pm 2.0$ \\
$1: 100$ & 0
\end{tabular}

Data are mean $\pm S E(n=3)$. The capillaries were incubated for 15 min with ${ }^{125} \mathrm{I}-\left[\mathrm{Tyr}^{11}\right] \mathrm{SRIF}$ and $\left[{ }^{3} \mathrm{H}\right]$ inulin followed by the addition of the antiserum dilution and incubation for an additional $15 \mathrm{~min}$.

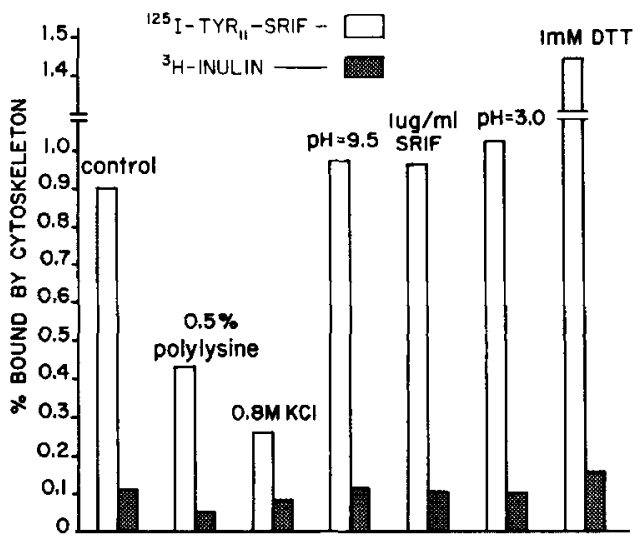

FIG. 6. The percent binding of ${ }^{125}$ - $\left[\right.$ Ty $\left.^{11}{ }^{11}\right]$ SRIF to Triton $X$ 100-resistant microvessel cytoskeleton at room temperature for a 10-min incubation is shown for a control and various experimental incubations. The open bars represent the percent binding of the SRIF and the closed bars represent the retention of $\left[{ }^{3} \mathrm{H}\right]$ inulin, an extravascular space marker. Polylysine and high concentrations of $\mathrm{KCl}$ inhibited the SRIF sequestration by the microvessel cytoskeleton and dithiothreitol enhanced the binding of the peptide to the cytoskeleton. However, none of these reagents altered the retention of the $\left[{ }^{3} \mathrm{H}\right]$ inulin extracellular space marker.

${ }^{125} \mathrm{I}-\left[\mathrm{Tyr}^{11}\right] \mathrm{SRIF}$ to the microvessel cytoskeleton was rapid and reached an equilibrium point by $5 \mathrm{~s}$ at room temperature (data not shown). In addition, the amount of [Tyr"]SRIF bound by the cytoskeleton was manyfold greater than the amount of $\left[{ }^{3} \mathrm{H}\right]$ inulin associated with the cytoskeleton (Fig. 6). Sequestration of the peptide by the cytoskeleton was not inhibited by high concentrations of unlabeled SRIF, by acid or alkaline $\mathrm{pH}$, but was inhibited by high concentrations of potassium chloride or another cation, polylysine, and was stimulated by $1 \mathrm{~m} M$ dithiothreitol (Fig. 6).

\section{Uptake of [Tyr $\left.{ }^{11}\right]$ SRIF by enzymatically} prepared microvessels

Bovine brain microvessels were prepared by a $0.5 \%$ dispase enzymatic homogenization technique (Materials and Methods), and sequestration of ${ }^{125} \mathrm{I}$ [Tyr $\left.{ }^{11}\right]$ SRIF by the dispase microvessels was studied. As shown in Table 3, the uptake of the

TABLE 3. Uptake of ${ }^{125} I-\left[T y r^{1 /}\right] S R I F$ by brain capillaries isolated with an enzymatic homogenization technique

\begin{tabular}{cc}
\hline Time & Percent bound/mg \\
\hline $5 \mathrm{~s}$ & $10.5 \pm 0.2$ \\
$0.5 \mathrm{~min}$ & $10.4 \pm 0.4$ \\
$1 \mathrm{~min}$ & $10.5 \pm 0.1$ \\
$10 \mathrm{~min}$ & $14.9 \pm 0.2$ \\
$30 \mathrm{~min}$ & $12.8 \pm 0.1$
\end{tabular}

Data are mean $\pm \mathrm{SE}(\mathrm{n}=3)$. The uptake of $\left[^{3} \mathrm{H} \mid\right.$ inulin, an extracellular space marker, was measured simultaneously and was subtracted from the measured uptake of ${ }^{125} \mathrm{I}-\left[\mathrm{Ty} \mathrm{r}^{11}\right] \mathrm{SRIF}$. The concentration of capillaries was $0.22 \mathrm{mg}_{\mathrm{p}}$ per $0.45 \mathrm{ml}$ incubation volume and the incubation temperature was $23^{\circ} \mathrm{C}$. 
peptide by the dispase capillaries reached equilibrium by $5 \mathrm{~s}$ of incubation at $23^{\circ} \mathrm{C}$ and was comparable in magnitude to that observed with the microvessels obtained by a mechanical homogenization technique, e.g., Table 2. The sequestration of [Tyr $\left.{ }^{11}\right]$ SRIF by the dispase microvessels was nonsaturable up to SRIF concentrations of $1 \mu \mathrm{g} / \mathrm{ml}$ (data not shown).

\section{DISCUSSION}

The present studies have led to two major findings. First, SRIF analogues such as [Tyr $\left.{ }^{11}\right]$ SRIF are rapidly and nonspecifically bound to the exterior of brain microvessels and also to the microvessel cytoskeleton. Second, $\left[\mathrm{Tyr}^{\mathrm{l}}\right] \mathrm{SRIF}$ is rapidly metabolized by capillary aminopeptidase and $\left[\mathrm{Tyr}^{11}\right] \mathrm{SRIF}$ is metabolized more slowly, presumably by a microvessel endopeptidase. Thus, the microvessel degradation of SRIF analogues is similar to the metabolism of SRIF in other tissues such as liver, where the clearance of [Tyr $\left.{ }^{1}\right]$ SRIF by liver is sixfold faster than the clearance of [Tyr $\left.{ }^{11}\right]$ SRIF (Sacks et al., 1984). In addition, Patel and Wheatley (1983) have shown that the major pathway of SRIF-14 degradation in vivo is via aminopeptidase. The rapid metabolism of SRIF-14 in vivo, $\mathrm{t}_{1 / 2}=0.5-1.3 \mathrm{~min}$ (Seal et al., 1982; Patel and Wheatley, 1983), is consistent with a major endothelial origin of the in vivo aminopeptidase activity.

The rapid nonspecific binding of [Tyr $\left.{ }^{11}\right]$ SRIF prevents the detection of any saturable SRIF receptors on the microvessel surface membrane, similar to the SRIF receptors identified on brain cell membranes (Srikant and Patel, 1981; Epelbaum et al., 1982; Reubi et al., 1982). Major concerns in this regard are (1) the parallel behavior of native SRIF and iodinated SRIF analogues, and (2) the possibility that the nonspecific binding of [Tyr $\left.{ }^{\prime \prime}\right]$ SRIF to the brain microvessel is an artifact caused by cell isolation or peptide iodination procedures. In regard to the possible physiologic significance of SRIF sequestration by brain capillaries, the following considerations are relevant. First, the high degree of nonspecific binding of [Tyr $\left.{ }^{11}\right]$ SRIF to the microvessel is not seen for all peptides. Acidic peptides, such as CCK8, or neutral peptides, such as leucine enkephalin, are bound very little, if at all, by the microvessels (Fig. 3). Moreover, another basic peptide, $\left[\right.$ Tyr $\left.^{8}\right]$ bradykinin, is bound only minimally compared with [Tyr $\left.{ }^{11}\right]$ SRIF (Fig. 3). Second, the uptake of [Tyr $\left.{ }^{11}\right]$ SRIF is not an artifact caused by isolation of microvessels with mechanical homogenization. Brain microvessels obtained with this technique are damaged by the shear force generated in even the gentlest mechanical homogenization and the capillaries do not exclude trypan blue (Pardridge and Mietus, 1981). However, brain microvessels can also be obtained by an enzymatic technique and these capillaries do exclude trypan blue (Bowman et al., 1983). We observed that microvessels obtained with this latter technique rapidly and actively sequester [Tyr ${ }^{11}$ ]SRIF (Table 3 ).

The sequestration of neuropeptides such as SRIF by brain microvessels could serve as a mechanism for rapid clearance of these neuropeptides from the brain interstitial space subsequent to neurosecretion. Indeed, the mechanism of inactivation of peptides by brain is at present unclear since presynaptic reuptake or postsynaptic degradation of peptides has not been documented, similar to what occurs for the amine neurotransmitters (Schwartz et al., 1981). Rapid binding of neuropeptides to brain microvessels could also anchor the peptide and make the compound accessible to capillary peptidases. For example, the rapid debinding of $\left[\right.$ Tyr $\left.^{11}\right]$ SRIF from the microvessels at $37^{\circ} \mathrm{C}$ (Fig. 4) suggests that significant endopeptidase activity occurs at physiologic temperatures.

Finally, the interaction of [Tyr $\left.{ }^{11}\right]$ SRIF with the Triton-resistant microvessel cytoskeleton is of interest since recent studies suggest that other neuropeptides, such as nerve growth factor, interact with the cellular cytoskeleton (Calissano and Shelanski, 1980). The data in Fig. 6 suggest that the SRIF/cytoskeleton interaction is resistant to acid or alkaline $\mathrm{pH}$ but is sensitive to cationic agents such as polylysine or potassium and is augmented by sulfhydryl reagents such as dithiothreitol. Since peptide interactions with the microvessel cytoskeleton might lead to changes in BBB permeability, the neuropeptide-microvessel cytoskeleton interactions may prove to be of physiologic significance.

Acknowledgments: This research was supported by NIH grants RO1-NS-17701, RO1-AM-33500, RO1-EY05205 , and by RCDA AM-00783. Janice Brothers skillfully prepared the manuscript.

\section{REFERENCES}

Bowman P. D., Ennis S. R., Rarey K. E., Betz A. L., and Goldstein G. W. (1983) Brain microvessel endothelial cells in tissue culture: a model for study of blood-brain barrier permeability. Ann. Neurol. 14, 296-402.

Brecher P., Tercyak A., Gavras H., and Chobanian A. V. (1978) Peptidyl dipeptidase in rabbit brain microvessels. Biochim. Biophys. Acta 526, 537-546.

Calissano P. and Shelanski M. L. (1980) Interaction of nerve growth factor with pheochromocytoma cells. Evidence for tight binding and sequestration. Neuroscience 5, 10331039.

Epelbaum J., Tapia Arancibia L., Kordon C., and Enjalbert A. (1982) Characterization, regional distribution, and subcellular distribution of ${ }^{125} \mathrm{I}^{2} \mathrm{Tyr}_{1}$-somatostatin binding sites in rat brain. $J$. Neurochem. 38, 1515-1523.

Goldstein G. W., Wolinsky J. S., Csejtey J., and Diamond I. (1975) Isolation of metabolically active capillaries from rat brain. J. Neurochem. 25, 715-717.

Hanko J., Hardebo J. E., and Owman C. (1982) Effects of various neuropeptides on cerebral blood vessels, in Cerebral Blood Flow: Effects of Nerves and Neurotransmitters 
(Heistad D. and Marcus M. L., eds), pp. 227-234. Elsevier North Holland, Amsterdam.

Heistad D. D., Busija D. W., and Marcus M. L. (1981) Neural effects on cerebral vessels: alteration of pressure-flow relationship. Fed. Proc. 40, 2317-2321.

Krieger D. T. and Martin J. B. (1981) Brain peptides. N. Engl. J. Med. 304, 875-885.

Lindvall M. and Owman C. (1981) Autonomic nerves in the mammalian choroid plexus and their influence on the formation of cerebrospinal fluid. J. Cereb. Blood Flow Metab. $1,245-266$

Lowry O. H., Rosebrough H. J., Farr A. L., and Randall R. J. (1951) Protein measurement with the Folin phenol reagent. J. Biol. Chem. 193, 262-275.

Olefsky J. M. and Kao M. (1982) Surface binding and rates of internalization of ${ }^{125} \mathrm{I}$-insulin in adipocytes and $1 \mathrm{M}-9$ lymphocytes. J. Biol. Chem. 257, 8667-8673.

Pardridge W. M. (1979) Carrier-mediated transport of thyroid hormones through the rat blood-brain barrier: primary role of albumin-bound hormone. Endocrinology 105, 605-612.

Pardridge W. M. (1983) Neuropeptides and the blood-brain barrier. Ann. Rev'. Physiol. 45, 73-82.

Pardridge W. M. and Mietus L. J. (1981) Enkephalin and bloodbrain barrier: studies of binding and degradation in isolated brain microvessels. Endocrinology 109, 1138-1143.

Pardridge W. M., Eisenberg J., and Yang J. (1985) Human bloodbrain barrier insulin receptor. $J$. Neurochem. (in press).

Patel Y. C. and Wheatley T. (1983) In vivo and in vitro plasma disappearance and metabolism of somatostatin-28 and somatostatin-14 in the rat. Endocrinology 112, 220-225.
Reubi J.-C., Rivier J., Perrin M., Brown M., and Vale W. (1982) Specific high affinity binding sites for somatostatin-28 on pancreatic $\beta$-cells: differences with brain somatostatin receptors. Endocrinology 110, 1049-1051.

Sacks H. S., Terry L. C., Wright R. K., and Stentz F. B. (1984) Somatostatin metabolism: differences in clearance of N-terminal and central portions of molecule during perfusion of rat liver. Am. J. Physiol. 246, G234-G266.

Schwartz J.-C., Malfroy B., and De La Baume S. (1981) Biological inactivation of enkephalins and the role of enkephalindipeptidyl-carboxypeptidase ("enkephalinase") as neuropeptidase. Life Sci. 29, 1715-1740.

Seal A., Yamada T., Debas H., Hollinshead J., Osadchey B., Aponte G., and Walsh J. (1982) Somatostatin-14 and -28: clearance and potency on gastric function in dogs. Am. J. Physiol. 243, G97-G102.

Srikant C. B. and Patel Y. C. (1981) Somatostatin receptors: Identification and characterization in rat brain membranes. Proc. Natl. Acad. Sci. USA 78, 3930-3934.

Uddman R., Edvinsson L., Owman C., and Sundler F. (1981) Perivascular substance $\mathrm{P}$ : occurrence and distribution in mammalian pial vessels. J. Cereb. Blood Flow Metab. 1, $227-232$.

Uddman R., Edvinsson L., Owman C., and Sundler F. (1983) Nerve fibres containing gastrin-releasing peptide around pial vessels. J. Cereb. Blood Flow Metab. 3, 386-390.

Yamada T., Marshak D., Basinger S., Walsh J., Morley J., and Stell W. (1980) Somatostatin-like immunoreactivity in the retina. Proc. Natl. Acad. Sci. USA 77, 1691-1695. 